\title{
The Gestation of Modern Gastronomy in Spain (1900-1936)
}

\author{
Ainhoa Aguirregoitia-Martínez ${ }^{1}$ and $\mathrm{M}^{\mathrm{a}}$ Dolores Fernández-Poyatos ${ }^{2}$ \\ ${ }^{1}$ University of Alicante. Campus de San Vicente del Raspeig- Ap. 99. 03080 Alicante \\ e-mail: aguirregoitia.ainhoa@gmail.com \\ ORCID iD: http://orcid.org/0000-0003-3392-3656 \\ ${ }^{2}$ University of Alicante. Campus de San Vicente del Raspeig-Ap. 99. 03080 Alicante \\ e-mail: dolores.fernandez@ua.es \\ ORCID iD: http://orcid.org/0000-0002-5771-3306
}

Submitted: 12 January 2017. Accepted: 17 February 2017

\begin{abstract}
This article discusses the gastronomic activity that took place in Spain between 1900 and 1936. It does so assuming that the modernisation process of Spain's gastronomy transpired during these years, which is the same period recognised for when modernity emerged in other areas. This approach has been possible due to the discovery and analysis of unpublished testimonies of that time, mainly obtained from the general illustrated and specialised trade press as well as treatises written by cooks and writers of the period and the contemporary literature on the subject. These findings support the existence of factors such as the desire to have a national culinary identity, the creation of the first training centres, the emergence of professional associations and the abundant production of cookery books, treatises and culinary magazines. All these elements enable us to outline and contemplate the formation of the modern structure of gastronomic activity, but above all, they enrich part of its history and highlight the advisability of conducting research in a field that is so important for Spain; namely gastronomy.
\end{abstract}

KEYWORDS: Gastronomy; History; Twentieth Century; Culinary; Spanish Modernity; Nationalism.

Citation / Cómo citar este artículo: Aguirregoitia-Martínez, A. and Fernández-Poyatos, M. D (2017) "The gestation of modern gastronomy in Spain (1900-1936)". Culture \& History Digital Journal, 6 (2): e019. doi: http://dx.doi.org/10.3989/ chdj.2017.019.

RESUMEN: La gestación de la gastronomía moderna en España (1900-1936).-Este artículo aborda la actividad gastronómica que existió en España entre 1900 y 1936, y lo hace desde la asunción de que fue entonces cuando se gestó la modernidad gastronómica, tal y como la historia reconoce dicha modernidad en otros órdenes. Este planteamiento ha sido posible gracias al descubrimiento y análisis de testimonios inéditos de la época, obtenidos sobre todo de prensa generalista, ilustrada y prensa especializada del sector, pero también de tratados de cocineros y escritores del momento, sin olvidar la bibliografía contemporánea al respecto. Estos hallazgos avalan la existencia de factores como el anhelo de una identidad culinaria nacional, la creación de los primeros centros formativos, los inicios de las asociaciones profesionales y la abundante producción de recetarios, tratados y revistas culinarias. Todos estos agentes permiten esbozar y plantear la conformación de la estructura moderna de la actividad gastronómica, pero sobre todo amplían una parte de su historia y sugieren la conveniencia de investigar en un ámbito tan importante para nuestro país como es el de la gastronomía.

PALABRAS CLAVE: Gastronomía; Historia; Siglo XX; Culinaria; Modernidad Española; Nacionalismo.

Copyright: ( 2017 CSIC. This is an open-access article distributed under the terms of the Creative Commons Attribution License (CC BY) Spain 3.0. 


\section{INTRODUCTION}

The level of maturity reached in Spain's gastronomy during the first third of the twentieth century in terms of its activity and professionalisation was not matched in many aspects until the 1970s, when the new Basque cuisine movement emerged, and until the end of the twentieth century in a broader sense, with Ferran Adrià. At that time, the evolution of Spain's gastronomy was determined by a confluence of new factors: the first gastronomy courses and teachings; the defence of a national cuisine; the emergence of professional associations; the publication of cookery books and culinary treatises and the birth of the trade press.

And this was despite the fact that Spain was lagging behind other nations at the beginning of the twentieth century, as it failed to fulfil the conditions that had enabled the industrialisation of the first comers ${ }^{1}$. In fact, Spain's delay in its incorporation into the industrialisation process meant that its inclusion in the new economic and social order was also delayed. In general terms, the historiography considers two essential facts: first, Spain's economic growth was insufficient to close the gap with respect to the large European countries; second, between 1913 and 1935, the economic pace accelerated thanks to the extension and diversification of industry; furthermore, Spain benefited from the First World War due to its neutrality. In addition to the industrial boom, the private banking sector was formed and the State began to express a desire to promote national production. This process of industrial modernisation, together with the increase in the population of the cities and the timid progress made in the social structure had an impact on consumption and therefore also on gastronomy.

Although Spanish society experienced a process of modernisation, it was not sufficient to give rise to a "consumer culture", at least in the current sense of the term; therefore the culinary renovation which began during these years should be exclusively understood as taking place within the privileged social classes - aristocrats and haute bourgeoisie. Through a trickling effect or osmosis, and given that the upper classes constituted a reference and model for the rest, the culinary revolution seeped through to the middle classes and eventually down to the working classes. This meant, in part, that culinary tastes were introduced and extended throughout extensive layers of society; in other words, the culinary culture was homogenised.

In addition, Spain had begun the twentieth century with the setback of the disaster of 98 which represented "a crisis of the national identity and patriotic values" [own translation] (Elizalde, 2000: 712) and an awakening of nationalism which extended to the economy, politics and the arts. We believe that the fanatical defence of the national cuisine by the most prominent gastronomes and chefs of the time was in some way related to the nationalist phenomenon.

The assertion of a national culinary identity had been expressed by Dr. Thebussem and Un cocinero de S. M. (pseudonyms of Pardo de Figueroa and Castro y Serrano, respectively) in their exchange of letters in La Ilustración Española y Americana between 1876 and 1877, when they called for menus to be written in Spanish (not French), criticised the excessive imitation of French cuisine and vindicated a national cuisine. This ideology was continued by prominent chefs and gastronomes during the first third of the twentieth century (Domènech, Bardají, Pardo Bazán and Dionisio Pérez) who, in their writings, continually praised and defended Spanish cuisine. Therefore it would seem right to consider that gastronomic nationalism was born within this trend which, as we have said, extended to the economic, social and cultural spheres.

The nationalist issue, together with other factors such as the mass production of publications, the concern for dignifying the culinary profession, the creation of the first training centres for professionals and academies to improve home cooking and the multiplication and strengthening of associations and trade unions with the consequent demand for rights and regulations to ensure dignified jobs, were prominent in the first third of the twentieth century. Their presence was sufficiently strong so as to associate the gestation of gastronomic modernity in Spain with this period.

This field of research, which has been highly developed in other countries such as France, Switzerland or Mexico, where an abundance of studies have been conducted on gastronomy over many years, has hardly been contemplated in Spain ${ }^{2}$. Our objective is to study how, during the period 1900-1936, Spain's gastronomic activity began its journey towards modernisation as a result of the convergence of the afore-mentioned factors and the existence of the circumstances necessary for the country to become a modern society: the growth of the population, the renovation of the production structures and the social changes (Arroyo, 2016: 190). Discovering part of this history constitutes the objective of this paper.

\section{THE DEFENCE OF NATIONAL AND REGIONAL CUISINE}

Spain's culinary tradition has not always had the recognition that it deserves. The French influence has been so strong that Spanish cuisine was overlooked and forgotten until the end of the nineteenth century when Mariano Pardo de Figueroa and José Castro y Serrano began the task of defending and promoting it as noted by Martínez (1981), Bueno and Ortega (1998) and Anderson (2013, 2014). They acknowledged that there were very few towns within Spain that did not have their own culinary speciality worthy of a prince's table, recommending that each of these recipes should be requested in order to compile "a repertoire of Spanish illustrious delicacies" [own translation] (1888: 180). In order to safeguard it, and in opposition to the French trend, Dr. Thebussem called for menus to be written in Spanish instead of French, for them to be free from spelling mistakes, incorporating artistic and typographic elements and to be signed with the 
name of the head chef in recognition of his work (Aguirregoitia and Fernández, 2015: 5). Un cocinero de S.M. warned of the consequences derived from excessively emulating French cuisine, the most serious of which was the detriment of Spanish cuisine.

Another testimony was the exchange of letters between Dr. Thebussem and Juan Valera called $N N \mathrm{~KB} C H$ (En escabeche y en sobremesa, 1906). It was a curious and almost unknown epistolary booklet issued by the author of Pepita Jiménez in 1888, which criticised the glorification of French cuisine to the cost of national dishes and insisted on the revival Spanish cuisine. To prevent the demise of Spanish gastronomy, he invited Thebussem to compose a book that would be called Regeneración nacional por virtud de la gastronomía y de otras artes castizas de bienestar y lícito deleite (Thebussem and Valera, 1906: 25). The death of Varera barely one month later cut short this enterprise which, due to the calibre of its participants would have constituted an erudite assertion of Spain's cuisine.

Other prestigious gastronomes and writers took part in this initiative, such as Ángel Muro, Emilia Pardo Bazán and Dionisio Pérez (Martín-Lorente and Fernández, 2014: 840), who sought to construct an idea of Spain's national cuisine which Spaniards would recognise as their own, although from different points of view (Anderson, 2013: 4).

Ángel Muro published his most important work in 1894: El Practicón: tratado completo de cocina al alcance de todos y aprovechamiento de sobras, which quickly became very popular, having thirty-four editions by 1920 and which he dedicated to his masters, Thebussem and Un cocinero de su majestad. Muro affirmed that this book contained his own recipes which he had put into practice (hence the name). However, the culinary nationalist issue was addressed only modestly in the book. On the one hand, Muro praised and respected French cuisine which he considered to be the best culinary representative of the moment; its legacy was undisputable. On the other hand, he acknowledged (Muro, 1894: 18) that Spain,

with this multiple variety of terrains and climates which make its territory fertile to excess, is the country that has the most elements for the best diet for all of its inhabitants. If Spain does not impose its cuisine on all other nations as is the case of France, this is due to its sobriety, which does not instill any other idea in its inhabitants than to eat to live and not to live to eat. However, the little that we eat we should eat well and we should condiment it in the best way possible, no matter where, with no thought to foreign or regional origins [own translation].

As verified by Anderson (2013: 77), Muro offered a polyphonic argument. While he asserted the diversity of climates, terrains and products and named stews as the national dish, he made a conscious effort to avoid discussing regionalism, as had his masters. Muro undoubtedly wrote the most representative treatise of Spanish cuisine of the moment.
Another representative of this nationalist current was Emilia Pardo Bazán, whose contribution took the form of La cocina española antigua (1913) and La cocina espanola moderna (1917). In the prologue of the first publication she addressed recurring issues such as feminism or the fight against the country's resistance to change but also Spanish gastronomy, the anthropological importance of cuisine and diet and the consideration of Spanish cuisine as opposed to French cuisine and the French who only wrote nonsense about the Spanish. Pardo Bazán insisted that each nation was obliged to conserve "what differentiated it, what formed part of its individual way of being. While it is good that we know how to cook French, Italian and even Russian and Chinese food, the base of our table, by law of nature, must be Spanish" [own translation] (Pardo Bazán, 1913: VI).

Dionisio Pérez also contributed to this debate in his column in La Voz between 1926 and 1930, imparting his culinary ideas and recipes, dishes and products of the Spanish regions. Some of the prominent themes were the protection of the national cuisine and its defence against French cuisine which he held in high esteem due to its contribution to culinary art, but which he condemned and even vilified when it claimed ownership of Spanish dishes and products such as mayonnaise, puff pastry or folded omelette. He even branded it as a plagiarist of other cuisines, particularly that of Spain and he openly claimed that the French dishonoured the glorious stoves of Spain's ancestors before the world ${ }^{3}$. His insistence on preserving Spain's culinary tradition is skilfully captured in his culminating work Guía del buen comer español (1929) and with great emphasis in Marmitón (19331934), the journal that he edited himself and which constituted a defence of the nationalisation of Spanish gastronomy.

Prestigious chefs of the time also debated national culinary unity. Their main representatives were Ignacio Domènech and Teodoro Bardají, forerunners of modern gastronomy in Spain. They were good friends and shared a concern for traditional cuisine and a determination to disseminate it. In their work and writings they insisted that Spain would not lose or be stripped of "this richness and this glory [and above all, that each day there was] a Spanish dish on each Spanish table prepared by Spanish hands" [own translation] (Pérez, 1929: 39).

There were others, such as José Serra - chef and owner of the Mundial Palace- who in El Arte Culinario, affirmed that the imitation of French cuisine was the reason why Spanish cuisine was a foreigner in its own home. He encouraged the re-conquest of national awareness and the destruction of the erroneous belief of its inferiority. This idea sought to generate a patriotic benefit responding to the national need to divulge a gastronomic culture that would be of interest. ${ }^{4}$

Although there were professionals in the sector who looked down on Spanish cuisine - considering it to be the worst of all ${ }^{5}$ - its defence was more prevalent, framed within a historical moment of surging nationalism and was often referred to in the press: 
[Spanish cuisine] is in a good moment with a great style. In a good moment because the revival of our awareness in terms of our national larder has now reached a reasonable level [..] and has great style because the folkloric base and the popular culture [...] of our cuisine want to combine with the elements of the noblest tradition $[\ldots]$ in order to achieve, through the only means possible, a high national style in our cuisine [own translation $]^{6}$.

Spain's cuisine was being reclaimed as an element of the country's identity ${ }^{7}$, being compared to its language, paintings, theatre, monuments and landscape (Hernández, 2013: 377-408): "National unity cannot be achieved without the unity of the language, the cuisine, the Law and the Architecture" [own translation $]^{8}$. This sentiment was shared by representatives of the national regenerationism, such as Azorín, who was tempted to say (and said) that "a country's cuisine is what best reveals and indicates its character" [own translation $]^{9}$. Moreover, this writer of the Generation of 98 proposed the study of culinary art together with Spanish culture, painting and architecture during those years when the country began to occupy a place in Europe that it deserved ${ }^{10}$, which, by extension, included its gastronomy.

Although Spain did not have a modern cuisine like France, it did have a culinary tradition and a delicious everyday cuisine worthy of being included in any menu, with each region having its own cuisine, meaning that the country had a varied, extensive and original gastronomy to show the world because "we have federated our cuisine, like we have federated the language and have federated and not united our uses and customs" [own translation] (Thebussem, 1888: 196). This gave rise to very different procedures, seasonings and stews, rendering a rich and diverse gastronomy. The gastronomes of the first third of the twentieth century knew this and therefore took on the task of rescuing it.

\section{THE BEGINNINGS OF THE PROFESSION}

\section{The first establishments}

The press and literature have always constituted major sources of news and descriptions related to dining and cuisine. From the Archpriest de Hita and his "Batalla entre don Carnal y doña Cuaresma" to Cervantes, Quevedo, Mateo Alemán, Francisco Delicado and Larra and his critical pen, there is an abundance of texts that recount Spain's culinary habits and customs. On the whole they did not portray the eating houses in a very good light, and from the end of the eighteenth century the inns were classified in terms of price ${ }^{11}$. The most expensive and with the highest category had good, clean staff, mild, expensive and delicate food and fresh and generous wines; the six real establishments also offered good dishes and service although they were more irregular; the five and four real establishments were similar to those in the previous category, only their staff were not as clean and the clientele were of a lower class and breeding; finally, in the three and two real establishments only measly stews were served "with a little meat, a handful of chickpeas, quasiimaginary lard and common vegetables" [own translation] (Torre y Leyba, 1774: 22-32).

From the eighteenth century, the Royal Spanish Academy dictionaries distinguished between bodegón, figón, mesón, hostería, posada, parador, taberna and venta (cheap restaurant, inn, roadhouse, tavern and country inn) ${ }^{12}$. These were the first establishments to serve meals. The fondas, cafes and restaurants entered the dictionaries later, which confirms that words are only registered when their occasional use becomes commonplace (Alvar, 1992).

In the nineteenth century, the establishments that served meals constituted a much smaller category than today. The documents of that time also refer to bodegones, tabernas and figones. They were very modest establishments that offered local cuisine and sometimes accommodation. They did not have a good reputation and received very negative appraisals from foreign travellers - Gautier, Dumas- and illustrious Spaniards, such as Larra, who, in articles such as Correspondencia del duende, La fonda nueva or El castellano viejo criticised the dreadful state of Spain's gastronomy, describing the awful table habits and the dirtiness, shortages and poor quality of many establishments. In a well-known comment he says "our country is not one where men live to eat; thankfully, rather, they eat to live [own translation]. ${ }^{13}$ " Writing about a fonda in Genieys, he comments that the dining rooms were very ugly with no decorations or any decent serving staff; in all of them, the diner was given "a filthy tablecloth and napkins, filthy glasses, filthy plates and filthy waiters [own translation $]^{14}$ ".

Richard Ford gave a less deplorable description in 1844. Referring to those establishments in the higher category, he claimed that some good dishes could be eaten there, such as cod, ham, eggs... and the hotpot, stew or national dish. Spanish chefs also had a bad reputation and their ruin was "their futile attempts to imitate the French" (Ford, 2008: 51).

This sad panorama improved somewhat during the first third of the twentieth century with the emergence of chefs and gastronomes that were concerned about the culinary issue, as we shall see later. In large cities such as Madrid, Barcelona, Valencia and Seville there was a progressive development of restaurants, maybe the best representative of the most delicate gastronomy or, according to Parra, the establishments that served food "with a certain tone, with a menu to choose from in the French or Russian style" [own translation] (Parra, 2008: 24). In Madrid, the Anuario del comercio, de la industria, de la magistratura y de la administración (Annuary of trade, Industry, magistracy and administration) of 1911 included seventy establishments, whereas the edition of 1900 only listed thirty-one. Furthermore, those associated to hotels were highlighted, such as the Gran Hotel y Restaurant de Rusia or La Parisina, as were cafes such as the Gran Café Restaurant de Zaragoza, where à la carte lunches were served. 
Some of them continue to be leaders in quality, maintaining the gastronomic history of their cities in their dishes, such as Casa Botín, Bodega de La Ardosa, Café Gijón, Casa Alberto, Casa Ciríaco, La Casa del Abuelo, Lhardy, Taberna Antonio Sánchez or Taberna Malacatín in Madrid;, Set Portes, Can Culleretes or Gaig in Barcelona; El Rinconcillo and Las Escobas in Seville and Casa Montaña in Valencia.

\section{The first associations}

The beginning of the professionalisation of the sector in Spain dates back to 1758 (Simón, 2011: 337-358) with the approval of the Ordenanzas del Gremio de Hosteleros y Figoneros de Madrid (first official regulations), which list the requirements for belonging to the trade such as, having worked as a master chef for two years, having passed an exam, being a person of good conduct with no contagious diseases, being the owner of only a hosteria and not a bodegón or taberna as well ${ }^{15}$.

At the end of the nineteenth century, the Constitution recognised the right to form associations. In 1887, the Ley de Asociaciones of 30 th June ${ }^{16}$ was enacted. This law governed the guilds and friendly societies. The professions of waiters and chefs were grouped into organisations and bodies or bulletins of expression were created, such as El Arte Culinario, El Cocinero Español, etc. (Simón, 2011: 342). From then on, applications to form societies to defend their rights were commonplace ${ }^{17}$.

One of the first societies was the Sociedad de Cocineros de Madrid, with its headquarters in Plaza del Carmen, 1 and 2, as recorded in the Anuario del Comercio de la Industria de la Magistratura y de la Administración de España of 1894 (306) which, three years later transferred to Mesonero Romanos, 34 (1897: 292).

Another important society was the Agrupación General de Entidades Profesionales, which on 11th December 1895 published a manifesto expressing the advisability of constituting an organisation with the objective of grouping together all the chefs, waiters and other employees of hotels, restaurants, cafés, fondas, public houses and similar of Madrid, in order to oversee the aspirations of the guild and the intellectual, moral and material improvement of its associates. ${ }^{18}$ The Agrupación was constituted on the $1^{\text {st }}$ January 1896. Despite internal problems, it operated until 1900 when the regulations were reformed and the number of associates increased. In 1903, there were four hundred members, mostly waiters. It became part of the UGT (General Workers Union) and published a ten-year report, La Solidaridad, as the trade entity.

Over time, the number of associations grew. In Madrid in 1900, the Sociedad de Cocineros y Camareros was established in calle Relatores, 2419; in 1903 El Arte Culinario and La Central de Camareros ${ }^{20}$ were formed and La Sociedad de Cocineras y Doncellas was established in calle Mayor, 1 in $1905^{21}$. Other similar associations were formed in other cities, such as the Sociedad Artística Culinaria de Barcelona in $1898^{22}$ or the Sociedad de Camareros, Cocineros, Reposteros y Similares, in Murcia in $1903^{23}$.
In the early decades of the twentieth century, these organisations acquired a certain degree of power due to the increasing number of members and their fight to defend their rights against the owners of the cafes and restaurants $^{24}$. In general, their grievances were related to earning dignified wages, improving their working conditions and having one day of rest per week. The Agrupación General had demanded a shortening of the length of the shifts, more hygienic establishments - particularly in the kitchen and service quarters - and the modification of wages together with the abolition of "the practice of tipping, which is uncomfortable for those who give the tips and does not favour the dignity of those who receive them" [own translation $]^{25}$.

Their members faced continual pressure and threats from employers who often called for them to leave the associations as they were dangerous for their interests. The strike called in 1903 in protest of the dismissal of workers from the San Millán café in Madrid and the continuous and widespread abuse by café and restaurant owners of their employees was very notorious ${ }^{26}$.

Another right that was not respected was the Sunday rest which, under the Law of 3rd March 1904, was developed in the Regulation of 19 April 1905. Its peculiarities did not contemplate the work related to the hotel and restaurant sector which gave rise to strikes and demands by chefs and waiters. This caused the Asociación de Fondistas y similares de España to request the inclusion of the work of waiters, servants, cooks, etc. of hotels, fondas and restaurants as an exception in Article 4 of this Regulation so that they could work on Sundays. This was granted through the Royal Order of 7th May $1913^{27}$.

Despite these early trade union movements, the working conditions did not seem to improve, working hours and rest days were not respected and discriminatory conduct prevailed among employees and hotel owners such as those of the Palace Hotel of Madrid which did not employ Spanish chefs. The different associations of the sector called on the Government for a modification and review of the laws to regulate foreign workers ${ }^{28}$. This behaviour could be interpreted as an indication of the poor quality of the work and training of Spanish chefs. An establishment such as the Palace Hotel logically sought to offer the highest quality, the best service, and therefore the best cuisine to its guests and could not afford any carelessness in its service. It had to establish itself on a solid reputation which was coherent with the category of the company; its philosophy consisted in hiring foreign chefs who, we assume, were mainly French. It was not in vain that the Spain's neighbour was by far the country of reference for European kitchens.

The issue of tipping was also a source of conflict. In September 1918, waiters and chefs in Madrid called for the abolition of tipping in exchange for higher wages. They also demanded their weekly rest day which had been regulated in the Royal Order of 30th January 1918 which granted these workers a whole day or two half days per week ${ }^{29}$.

In other regions of Spain, the situation was similar. In Zaragoza, a strike began among hotel and fonda chefs in 
1920 who demanded a fifty percent increase in their daily wages $^{30}$. In the same year, in different cities (Valencia, Gijón, Barcelona and Madrid) more strikes were held by chefs and kitchen hands of cafes, fondas and similar establishments ${ }^{31}$, who demanded better wages. It was not without reason that in the years following the First World War there were serious social crises, with frequent strikes and proletarian unrest. The working class movement, inside and outside of Spain, had begun its fight, in all sectors, for social wellbeing, demanding dignified working hours and wages and improved hygienic conditions and a reduction of the eleven or twelve hour working day demanded of them by the owners and employers.

Another phenomenon that prevailed during these years was the merger of societies. In 1923, the associations in Madrid joined together, namely the El Arte Culinario Español, El Arte Culinario and the Grupo Sindicalista de Cocineros, "only a small group of Catholics remaining outside" [own translation], according to the article published in La Libertad on $24^{\text {th }}$ May 1923. Through this action they sought to reinforce themselves as an organisation in order to claim their rights and denounce the abusive treatment of bosses and owners.

In general, almost all of the associations published bulletins as channels of expression and information. The afore-mentioned El Arte culinario. Órgano de la Sociedad de Cocineros y Reposteros (1907-1911) was one of the first and most important in Cadiz; in 1928, the Revista del Arte Culinario, órgano de la Sociedad del Arte Culinario Español founded in 1919 with Teodoro Bardají as its secretary, merged with the Federación Culinaria (1927-1929), which was the official publication of the Federación Nacional de Cocineros y Aspirantes de España; in 1928, the Revista culinaria: órgano de la Asociación Profesional de Cocineros de Cataluña was founded, as was the Boletín del Cocinero: Revista Culinaria, which was the official voice of the Asociación Artística Culinaria de Cataluña (1935). All of them constitute invaluable documents for learning about the sector during that period.

\section{CULINARY TRAINING}

Between 1900 and 1936, culinary training in Spain began to acquire a professional dimension. The first centres were aimed at women, as they were responsible for feeding their families: "Married women know this well; single women, always so perceptive, know that this is a charming quality to have" [own translation] ${ }^{32}$ " They were probably emulating those schools existing in London, such as the Nacional Training School of Cookery, established in 1873, or in Germany, such as the Karlsruhe model school of cookery ${ }^{33}$.

In 1901, Félix Ibarguren and Loreto Capella opened the Academia de Cocina de San Sebastián (The San Sebastián Academy of Cookery), where classes for the modern education of women were taught ${ }^{34}$. In 1911, the EScuela de Hogar y Profesional de la Mujer (Home and Professional School for Women) was founded in Madrid.
Its most prominent teachers included Melchora Herrero and Ayora, writer and author of highly popular culinary treatises such as El arte de la cocina: fórmulas experimentadas en la Escuela del Hogar (1914) and Cocina selecta y clásica (1927). In 1920, according to Simón (2011: 347), the Cooking Academy was created in Madrid, where the head teacher was Ignacio Domènech. The classes were aimed at improving the education of young women so that they could become complete directors of their households. Domènech continued this teaching activity in Barcelona with the opening of the Centro Social de Belén on the 8th April 1923 which would give "practical home cooking lessons for young women" [own translation $]^{35}$.

Another popular institution in Madrid was the Academia Gastronómica, created in 1933 to teach young ladies to $\operatorname{cook}^{36}$. It was directed by José Sarrau, a wellknown chef and prolific writer of popular cookbooks. He also edited the text books that were used in the classes.

However, the sector also called for quality training in order to improve the qualifications of its professionals. Simón (2011: 345) refers to news report of $1910^{37}$ that the Asociaciones de Fondistas de España, similarly to the campaigns initiated in France, Switzerland, Italy and Portugal to increase tourism, had, in 1906, proposed the activation of propaganda and the organisation of assemblies and congresses in order to reform hotels and acquire competent staff with knowledge of languages; however, the agreements that they proposed "were terrible for the Spanish chefs and waiters, as the immense majority did not speak languages and had no knowledge other than the routine practices that they had been taught [own translation $]^{38}$ ". The failure of this initiative gave rise to another that was more successful. In fact, in October 1908, the Asociación Fondista Española and the societies of waiters and cooks in Madrid, namely the La Central de Camareros, El Alba and El Arte Culinario opened a School of fondistas ${ }^{39}$ called the Escuela Española de la Industria Hostelera, whose director was José Romay and not, as claimed by Simón (2012: 18), Ignacio Domènech who held the position of librarian ${ }^{40}$. The Reglamento $y$ plan de estudios de la Escuela Española de la Industria Hostelera [Regulations and study plan of the Spanish School of the Hotel and Restaurant Industry] ${ }^{41}$ (signed on 1st February 1909), which as far as we know remained unpublished, is conserved in the National Library. Its objective was to provide the professionals of the sector "the greatest possible knowledge related to culture in general and specifically to the café and restaurant professions" [own translation] (Reglamento, 1909: 3). But it also sought to contribute to developing tourism and trade in Spain, organising conferences, a library and improving the conditions of its employees (Reglamento, 1909: 3-4).

The teaching was organised into an elementary block and a superior one ${ }^{42}$. The study plan contained in the Reglamento explained in its first article that there would be two types of teaching: non-valid courses and those with validity recognised by the Asociación Fondista Española y Asociación de Cafeteros de Madrid" (Regla- 
mento, 1909: 17). The teaching plan with validity was divided into elementary and superior parts; the elementary part, which had to be passed entirely in order to continue further, was made up of two courses with elementary contents of arithmetic, handwriting, geography, French, cooking, baking, the preparation of cocktails, punches, hors d'oeuvres, drinks, etc. (Reglamento, 1909: 18).

Once these subjects had been passed, the students had the possibility of continuing with the higher education and obtaining the qualification of director, manager of administrator of hotels, fondas, restaurants and cafes. Students were required to pass a four-year course. Additional subjects included English and German as well as French, business mathematics, knowledge of the cleaning of furniture and gilding, legislation, regional customs, electrical studies, machinery, monetary studies, railway studies, the management and creation restaurants, cafés, hotels and the composition of menus.

The Escuela Española de la Industria Hostelera also contemplated other courses: Culinary training, courses for waiters and also for interpreters.

The Culinary School taught six-year long courses. In order to enter the school, students were required to sign up to French and decorative drawing, be at least fourteen years old and have passed at least two years of Spanish language study, French, drawing and accounting. The first part of the course was taught over two years and the second over a period of four years (Reglamento, 1909: 20$22)$. The programme was very comprehensive: for the first two years, the subject material related to meat, fish, cakes and pastries, legumes, ice-cream, biscuits and creams. The second part of the course, covering a period of four years, was related to more elaborate and complex techniques: soups with nutritious and aromatic elements, consommés with garnishing, creams, regional and foreign soups, stocks (pale, white, game, fish, essence of fish, meat, poultry, truffle), mother sauces, gelatine, garnish, all types of fried food, fine cakes and pastries and American and English soft drinks.

The study plan is surprising due to the variety of subjects and the length of the courses. In fact, it was very similar to a university degree. Despite the good intentions of some of the forerunners, the professional schools were insufficient and were privately run. In contrast, in neighbouring countries such as France, Switzerland or England there were many waiter and cookery schools, with a long historic tradition, which even today have renowned study plans in the field. There are testimonies that report that in Austria and Germany in 1902 there were already one hundred and fifty cookery schools with four-year courses after which the students received an official qualification ${ }^{43}$.

\section{CULINARY KNOWLEDGE: TREATISES AND JOURNALS}

Another factor considered for evaluating the gestation of gastronomic modernity in Spain is the publishing of culinary treatises and journals. During the first third of the twentieth century, many cookery books, magazines and bulletins of professional associations were published, which shows that the marginalisation of Spain in terms of its food and gastronomic history is unfair. According to Simón, Spain was one of the first countries to undertake publishing activity: it is estimated that from the introduction of printing to 1900 almost two thousand editions were published (Simón and Ansón, 1997: 125-126). Furthermore, between 1900 and 1936, production was huge with around two hundred new titles and the total number of editions easily exceeded two thousand with the re-editions of the majority of these publications ${ }^{44}$.

The subject matter was varied: cookery and classic and modern baking, regional cuisine from Catalonia, $\mathrm{Na}-$ varre, Mallorca and the Basque Country, products such as mushrooms, economical cooking, cooking for lent, vegetarian cuisine, nutrition, food hygiene or recipe books edited by prestigious brands, such as Anís del Mono which gave away free booklets with twenty three recipes to its customers or Maggi which, in the 1930s published Recetas prácticas para la cocina.

With respect to books, many were recipe books written by cooks and amateur gastronomes who sought, above all, to share recipes in order to improve home cooking ${ }^{45}$. However, there were very few books aimed at professionals and La cocina original española written by José Gómez González in 1931, which claimed to be a compendium of cooking, the most complete book published in the field and one that was essential for chefs and apprentices, hoteliers, etc., was one of the few texts aimed at the professional sector.

Prominent writers of the time, such as Camba, Puga $y$ Parga (Picadillo), Pardo Bazán, Carmen de Burgos (Colombine) and Dionisio Pérez were interested in the culinary art and published recipe books and reflections on the country's gastronomy.

The book written by Julio Camba, La casa de Lúculo (1929), stands out for its scathing irony and fierce criticism of Spain's customs and cuisine. For him, Spain was a country dominated by garlic and religious concerns, where pork was useful to old Christians so that they could distinguish themselves from the converted Moors and Jews. Camba highlighted the superiority of butter over oil, which he claimed was lacking in vitamin $\mathrm{E}$ and responsible for the short height of Spaniards. However, he also referred to the excellent fried fish from Andalusia of which he commented "there will never be a kitchen anywhere else in the world that will be able to match them" [own translation] (Camba, 2013: 8). Furthermore, he criticised the chickpeas and stews which he said were not a national dish but only another variety of a universal dish. He was not wrong when he said that Spain's cuisine had no direction, that there was no gastronomic capital to inspire the regions or at least, brought together the regional inspirations. Although he acknowledged that Spaniards had renovated the old cuisine thanks to the discovery of America and the introduction of its products to Europe, they had neglected their own cuisine.

The Coruña-born Puga y Parga left an important legacy of Galician recipes and how to cook cod in fifty-six 
different ways (1913). His books include La cocina práctica, written in 1913, with a prologue by his friend Pardo Bazán who described his cuisine as classic and traditional, "not in the old Spanish way, old-age marinating, dishes from my childhood times, family dishes, the friend flavours" [own translation] (Puga y Parga, 1913: XIII).

Dionisio Pérez, mentioned above, contributed to the knowledge of Spanish cuisine with the Guia del buen comer español. Published in 1929 by the National Tourism Board, it was probably the best culinary repertoire of the time. As well as unyieldingly defending Spanish cuisine, Pérez compiled an excellent, erudite and unparalleled collection of Spain's regional cuisine.

Female scholars and authors also contributed to gastronomic training and literature. However, their role was largely insignificant, perhaps because contemporary chefs, such as Domènech and Bardají underestimated and criticised some and ignored others, and so they soon became forgotten. Pardo Bazán, Carmen de Burgos, Melchora Herrero or the recently re-discovered María Mestayer de Echagüe were denied their role as sources of knowledge (Ballarín, 1999: 82).

The illustrious journalist Carmen de Burgos (Colombine), a cookery teacher at the arts and industry school of Madrid, left several recipe books in her huge legacy: ¿Quiere usted comer bien?, La cocina moderna, La cocina práctica and Nueva cocina práctica. In the prologue letter of the second, she writes to Francisco Sempere, one of her critics, with fine irony: "Damn that Sempere! How did he find out that I cook better than I write? [...] Sometimes, watching the joy and appetite with which [my family clean] their plates, I have felt the same hint of vanity that I experience when somebody who has not ready my articles praises them" [own translation] (Burgos, 1918: V). Colombine was one of the vilified writers of the time; it is not surprising that her activism in favour of women's rights and her personal and literary life were used by the extensive misogyny of the time to first ridicule her and then forget her.

Melchora Herrero y Ayora was a teacher and director of the Escuela de Hogar y Profesional de la Mujer which opened in Madrid in 1911; she wrote, together with her sister Florencia, very popular culinary treatises: El arte de la cocina: fórmulas experimentadas en la Escuela del Hogar (1914) and Cocina selecta y clásica (1927). Largely unknown, her work as a promoter of culinary training was constant and innovative. Not only did she seek to explain in a clear and simple way how to prepare food as a result of her daily experience in the school, but she also sought to provide "economic, hygienic and nutritious formulas for rapid food preparation" [own tranaslation $]^{46}$. She did not write them in the traditional way of the treatises of the time, but by first listing the ingredients of the recipe and the precise amounts in grammes, litres, etc, as the leading chefs did.

María Mestayer de Echagüe, better known by her pseudonym Marquesa de Parabere, also collaborated in several gastronomic publications, two of which -Confitería y repostería published in 1930 and La cocina comple- ta first published in 1933- reached their eleventh editions in 1963 and 1964 respectively. The second was her most popular work, and on the contrary to the national culinary regenerationist movement, it had a clear French influence and became a reference text for generations of professionals and gastronomes (Echagüe and Echagüe, 2013: 13). However, there were many more. It is worth mentioning, at least, Matilde García del Real, Carmen Farinós y Gispert, Isabel Gallardo, Adriana de Juaristi, Duquesa Martell, Magdalena Ortiz, Mercedes Martín, Concepción Pérez, Nicolasa Pradera and Genoveva Bernard.

However, the contribution to a technically refined cuisine was made by professional chefs such as Ignacio Domènech or Teodoro Bardají, both representatives of the revival of Spain's gastronomy (Bueno and Ortega, 1998; Martín, 2008; Simón, 2012). While Bardají published a few yet invaluable publications ${ }^{47}$, Domènech was a prolific writer who published more than thirty culinary books. They both actively disseminated their culinary knowledge through the illustrated magazines of the time, the professional press and bulletins of the sector. Bardají even participated in Radio España with "Recetas culinarias", a programme sponsored by the magazine Ellas ${ }^{48}$. Years before, in 1927, Unión Radio had broadcast cookery programmes; specifically, we can refer to the show of Gonzalo Avello which aired between 1927 and 1934 on the Madrid station called Recetas culinarias. Plato del día ${ }^{49}$.

Important magazines in the sector were also published during this period. They reported the testimonies of renowned chefs and gastronomes such as Domènech, Bardají, Brizuela and Dionisio Pérez: La Cocina Elegante. Revista Culinaria Quincenal (1904-1905), El Gorro Blanco (1906-1945), Cocina Artística y Casera (19171918), Marmitón (1933-1934), Paladar (1933-1934), Menage (1933-1948). Official publications of the different culinary associations were also published, such as El Arte Culinario (1907-11), Confitería y Pastelería. Revista Mensual Hispano-Americana. Ilustración y Defensa de las Artes de Confitería, Pastelería y Chocolatería, Órgano Oficial del Centro Industrial de Confitería y Pastelería from Barcelona (1912), Federación Culinaria (19271929) or Revista Culinaria (1928-1929) from Catalonia.

Worth highlighting is El Gorro Blanco which was published by Domènech between 1906 and 1945. Its pages include a wealth of Domènech's culinary knowledge

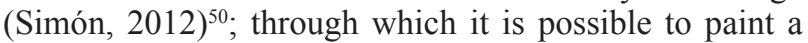
picture of Spain's gastronomic scene: names, recipes and everything related to the cuisine of the leading Spanish and foreign head chefs: economic dishes; liquors and soft drinks; biographies of colleagues and important figures in the sector. Scientists specialising in nutrition and gastronomic writers also collaborated in this publication with translations of recipe books and magazines and culinary history books, including the publication in instalments in 1910 of La mesa moderna by Dr. Thebussem and Un cocinero de S. M. It also re-printed articles published in other magazines, written by the likes of Dionisio Pérez, Fernández Flórez, Noel, etc.; and also had a section of interesting facts called "Quisquicosas culinarias". Ac- 
cording to Domènech himself (Simón, 2012: 13-20), the best chefs and pastry cooks in Spain and abroad wrote for the publication, including Bardají, Loreto Capella, Melquíades and Brizuela.

In general terms, the professional publications sought to dignify the culinary art in order to bring it out of its state of stagnation and disseminate and nationalise Spain's gastronomic culture. They had a wide and diverse readership: the aristocracy, the middle class and even the more modest classes, but also housewives and mothers and even men of letters and business.

The majority of these journals shared certain sections: From historical menus and grand recipes by important writers and chefs to simple, economic menus for the middle class and also proposals for everyday home cooking. However, the relevance of their articles resided in the abundance of innovative themes, such as cost evaluation ${ }^{51}$, the organisation of contests and fairs to disseminate Spain's products and cuisine, the use of advertising as a promotional technique, offering cooking classes at home in exchange for Corona butter coupons. ${ }^{52}$, the series of postcards with prints of finished recipes by famous chefs ${ }^{53}$, the description and praise of seasonal products in order to favour their consumption ${ }^{54}$, news about publications, books and conferences, sections on culinary techniques or sessions on cocktail preparation. Medicine also had its place, with a concern for hygiene, health and diet being recurrent topics in the journals. This reveals that Spanish gastronomes knew about the in-vogue themes of the time, one of them being health which Spanish society was highly interested in. The written dissemination of gastronomy was, undoubtedly, essential for improving the professional and domestic culinary activity but also for contributing to the enjoyment of food and healthy diets.

\section{CONCLUSIONS}

The study reveals that it is possible to pinpoint the beginning of the gestation of Spain's culinary modernisation during the first third of the twentieth century. In fact, a gastronomic renovation took place which, while benefiting the upper classes (aristocracy and bourgeoisie), also gradually filtered down to the middle and working classes who looked to the higher classes as a reference. Evidence of this theory is the role that the press had as a channel of dissemination. A previous study has partly analysed this phenomenon and reveals the abundance of news and articles and newspapers and illustrated press during the nineteenth and twentieth centuries ${ }^{55}$, acknowledging the interest that Spanish society had in the subject. This study provided us with a source of many documents - some unpublished -, and numerous titles of publications of the period. These documents have revealed the importance acquired by the following factors: the defence of a national cuisine, the emergence of professional associations, the first training centres and the publication of recipe books and culinary treatises and magazines.

Spain's national cuisine was discussed at length; on the one hand a more dignified role was demanded for
Spain's gastronomy for which it was necessary to stop imitating (often exaggeratedly) the French; on the other hand, there was a desire for Spanish cuisine to be appreciated for which it was necessary to learn about it, study it and then apply it. However, one of the most important issues revolved around the existence or not of a national cuisine which differentiated Spain from other countries and which gave it its own culinary identity. This fact has been understood as forming part of the nationalist currents that were emerging in the economy, society and culture at that time. Some of the testimonies analysed praise the cuisine to such an extent that it is compared to other identifying elements of the country such as its landscapes, monuments or paintings. However, the improvement of Spain's gastronomy was also seen as an element to attract the incipient tourist flows of the first third of the twentieth century.

Furthermore, it was necessary to revive and dignify Spain's cuisine. Above all, there was an urgent need to improve it and disassociate it from the appalling reputation that foreign writers had given it. Without a doubt, the professionalisation of the sector was one of the ways that would help achieve this. During these years, there was a strong associative movement in the sector through which the right to Sunday rest, dignified wages and the shortening of the working day or the improvement of the hygienic conditions were demanded, the results of which remain in force to the present day. In this respect, the research conducted by Simón $(2011,2012)$ constitutes an essential starting point.

The other route for professionalising the sector, was, undoubtedly, training. In 1908 the Escuela Española de la Industria Hostelera was opened, the first educational centre with an ambitious programme of languages, geography and accounting with a course duration of six years. However, the efforts would not have been successful without the culinary knowledge contributed by illustrious chefs, writers and gastronomes and their many publications. Their knowledge can be found in the treatises and general and specialised press, constituting a legacy that none of the other gastronomic movements of Spain's history is able to equal. Recovering this legacy has also been one of the objectives of this study.

\section{NOTES}

1 Used in economics to refer to the first countries to become industrialised.

2 An important exception are the works of Simón on the bibliography (Simón and Ansón, 1997 and Simón, 1999), the beginnings of the profession (Simón, 2011) and Ignacio Domènech (Simón, 2012). Also, those of Pérez Samper $(1998,2009)$ on the history of food.

3 Nuevo Mundo [NM] "El fogoncillo nacional de Post-Thebussem”, 24 January 1930: 57. http://hemerotecadigital.bne.es/issue.vm?id=0002159162\&search=\&lang=es. [accessed 13/ March/2016].

4 El Arte Culinario [EAC] "Un concurso culinario netamente español", 31 October 1911: 2. http://www.bibliotecavirtualdeandalucia.es/catalogo/publicaciones/numeros por mes.cmd?idPu blicacion=1033073\&anyo=1911. [accessed 22/May/2015]. 
5 The article published in Pluma y Lápiz on 1 January 1902 written by Rodolfo Leblanc is highly illustrative. Leblanc was an ex kitchen hand at the Gran Hotel La Paz de París, and in the article he describes the kitchen as one of listless misers which was ghastly due its grease and an appetite destroyer.

$6 A B C$ "Cuestión de la cocina española", 26 September 1929: 3-4 and 6.

7 For the concept of identity, see the studies by (Sanz-Cañada and Muchnick, 2016 and Renard and Thomé, 2016).

$8 A B C, 26$ September 1929: 3. http://hemeroteca.abc.es/nav/Navigate.exe/hemeroteca/madrid/abc/1929/09/26/003.html. [accessed 01/April/2016].

$9 A B C$ "España. Guisos", 21 September 1929: 3. http://hemeroteca.abc.es/nav/Navigate.exe/hemeroteca/madrid/abc/1929/09/21. html\#003. [accessed $05 /$ April/2016].

$10 A B C$ "España. Guisos", 21 September 1929: 4. http://hemeroteca.abc.es/nav/Navigate.exe/hemeroteca/madrid/abc/1929/09/21. html\#003. [accessed $05 /$ April/2016].

11 A documented study on these establishments in Zaragoza is that of (Parra de Mas, 2008).

12 We have not referred to the Tesoro de Covarrubias because it is from 1611 and does not refer to the terms at the start of this profession; these terms can be found in the editions of the Diccionario de la lengua castellana, for the years 1732, 1734, 1737, 1739, 1780 and 1791.

13 Revista Española [RE], 23 August 1833: 1. http://hemerotecadigital.bne.es/issue.vm?id=0003595930\&search=\&lang=es [accessed 18/April/2016]

$14[R E], 23$ August 1833: 4. http://hemerotecadigital.bne.es/issue.vm ?id=0003595930\&search=\&lang=es. [accessed 18/April/2016].

15 Simón reproduces this in its entirety in her study (Simón, 2011: 352-358). The original can be consulted in the Biblioteca Histórica Municipal de Madrid. http://catalogos.munimadrid. es/cgi-bin/historica/O7143/ID0a4f30cf?ACC=261. [accessed 1/ December/2016].

16 Gaceta de Madrid [GM], 12 July 1887. https://www.boe.es/datos/pdfs/BOE//1887/193/A00105-00106.pdf. [accessed 5/ May/2016].

17 Las Dominicales del Libre Pensamiento [DLP], 21 June 1890: 2. http://hemerotecadigital.bne.es/issue.vm?id=0002626947\&s earch=\&lang=es. [accessed 2/February/2016].

18 El Globo [EG], 18 October 1903: 2. http://hemerotecadigital. bne.es/issue.vm? $\mathrm{id}=0001248159 \&$ search $=\&$ lang $=$ es. [accessed 25/July/2016].

19 Anuario del comercio, de la industria, de la magistratura y de la administración [ACIMA], 1900: 293.

$20[E G]$, 1 June 1903: 2. http://hemerotecadigital.bne.es/issue.vm? $\mathrm{id}=0001246190 \&$ search=\&lang=es. [accessed 12/June/2016].

21 [ACIMA], 1905, 547.

22 [ACIMA], 1898, 942

23 Archivo General Región de Murcia. ES.30030.AHP/05 / Gobierno Civil de la Provincia de Murcia (1822-1999) > 5.4 / Asociaciones y orden público. Derechos ciudadanos (18881986). $>$ 5.4.2/ Asociaciones > 5.4.2.2/ Registros de asociaciones (1888-1927). > GOB,6580/16 / Registro de Asociaciones: $n^{\circ}$ 801-850. Años 1903-1904. http://archivoweb. carm.es/archivoGeneral/arg.muestra_detalle?idses $=0 \&$ pref $\mathrm{id}=3789499$. [accessed 25/January/2016].

24 We know from (Simón, 2011: 343-344) that the Estatutos de la Federación de Camareros, Cocineros y Ayudas de Cámara were published by Ignacio Domènech in his magazine El Gorro Blanco.

$25[E G], 18$ October 1903: 2. http://hemerotecadigital.bne.es/issue.vm? id=0001248159\&search=\&lang=es. [accessed 25/ July/2016].

$26[E G]$, 5 June 1903: 3. http://hemerotecadigital.bne.es/issue.vm? $\mathrm{id}=0001246247 \&$ search=\&lang=es. [accessed 29/June/2016].

$27[G M], 9$ May 1913. https://www.boe.es/datos/pdfs/ BOE//1913/129/A00377-00377.pdf. [accessed 05/August/2016].

28 La Época [LE], 3 November 1912: 3. http://hemerotecadigital. bne.es/issue.vm?id=0000823390\&search=\&lang=es. [accessed 12/August/2016].
$29[E G], 26$ September 1918: 2. http://hemerotecadigital.bne.es/issue. $\mathrm{vm}$ ?id=0001456970\&search=\&lang=es. [accessed 13/June/2016].

$30[E G], 26$ May 1920: 1. http://hemerotecadigital.bne.es/issue.vm ?id=0001472875\&search=\&lang=es. [accessed 24/June/2016].

$31[E G], 23$ July 1920: 2. http://hemerotecadigital.bne.es/issue.vm ?id=0001474668\&search=\&lang=es. [accessed 25/June/2016].

32 Estampa, 14 January 1933: 5. http://hemerotecadigital.bne.es/ issue.vm?id=0003451401\&search=\&lang=es. [accessed 11/ July/2016].

33 Revista General de Enseñanza y Bellas Artes [RGBA], 15 April 1915: 7. http://hemerotecadigital.bne.es/issue.vm?id=00039916 $04 \&$ page $=7 \&$ search $=\% 22$ hostelera $\% 22+\% 22$ cocina $\% 22 \&$ lang $=$ es. [accessed 22/March/2016].

$34[N M], 5$ March 1902. http://hemerotecadigital.bne.es/issue.vm? $\mathrm{id}=0001292574 \&$ search=\&lang=es. [accessed 14/March/2016].

35 La Vanguardia [LV], 7 April 1923: 5. Although (Simón, 2012: 4) affirms that it opened on 19th May 1923, it does not seem as though this was the case, as there is an abundance of articles in La Vanguardia during April and May, informing of the continuation of the classes under Domènech, which, according to the same newspaper, were taught in June. http://hemeroteca.lavanguardia.com/preview/1923/04/07/pagina-5/33275260/pdf. html?search=Domènech. [accessed 26/April/2016].

36 Estampa, 14 January 1933: 3-6. http://hemerotecadigital.bne. es/issue.vm?id=0003451401\&search=\&lang=es. [accessed 11/ July/2016].

37 Revista General de Enseñanza [RGE], 15 March 1910: 5-6. http://hemerotecadigital.bne.es/issue.vm?id=0003771149\&sear $\mathrm{ch}=\&$ lang=es. [accessed 26/June/2016].

38 [RGE], 15 March 1910: 5.

39 The Madrid newspapers that reported the event included $A B C$, 29 October 1908: 12 and El Globo, 30 October 1908: 2. http:// hemeroteca.abc.es/nav/Navigate.exe/hemeroteca/madrid/ abc/1908/10/29.html [accessed 30/June/2016].

40 [EG], 30 October 1908: 2. http://hemerotecadigital.bne.es/issue.vm? $\mathrm{id}=0001314088$ \&page $=2 \&$ search $=\&$ lang $=$ es. $\quad$ [accessed 30/June/2016].

41 Reglamento y plan de estudios de la Escuela Española de la Industria Hostelera [REEIH] (1909). Madrid, A. Velasco Impresor.

42 ([REEIH] 1909: 18). Simón published a summary of the programme (Simón, 2011: 344-345); however, we do not know the source used, although we believe that it could have been drawn form an article published in the magazine El Gorro Blanco by Ignacio Domènech.

43 Alrededor del Mundo, [AM], 15 August 1902: 108. http:// hemerotecadigital.bne.es/issue.vm? $\mathrm{id}=0001822430 \&$ search $=\&$ lang=es. [accessed 26/May/2016].

44 These approximate data have been extracted from Simón who has complied the works published in Spain from the beginnings of printing to 1975, in particular, the chapter on the twentieth century (Simón, 2003: 274-401). It is the result of her research following the Unesco agreement to create a Universal Gastronomy Library (1997; 1999 y 2003).

45 See the studies by (Luján and Perucho, 1974 and Martínez, 1981).

46 La Escuela Moderna [EM], 1 June 1918: 380. http://hemerotecadigital.bne.es/issue.vm?id=0001509920\&search=\&lang=es. [accessed 11/July/2016].

47 An interesting compilation work on the work of Bardají is that of Martín (2008)

48 Ellas, 23 December 1934: 20. http://hemerotecadigital.bne.es/ issue.vm? $\mathrm{id}=0003722542 \& \mathrm{search}=\&$ lang=es. [accessed 12/ August/2016].

49 Ondas, 21 January 1927: 18. http://hemerotecadigital.bne.es/issue.vm?id=0003578589\&search=\&lang=es [accessed 18/September/2016].

50 The study not only describes the content of the magazine but also the publishing work of Ignacio Domènech.

51 Cocina Artística y Casera [CAC], 20 September 1917: 13. http://hemerotecadigital.bne.es/issue.vm?id=0004932465\&sear $\mathrm{ch}=\&$ lang=es. [accessed 7/October/2016]. 
52 Marmitón, November 1933: 13. http://hemerotecadigital.bne. es/issue.vm?id=0005275569\&search=\&lang=es. [accessed 11/ October/2016].

53 El Gorro Blanco [GB], 1910: 202.

54 Paladar, 1 June 1933.

55 The results can be found in (Aguirregoitia and Fernández, 2015).

\section{REFERENCES}

Aguirregoitia, Ainhoa and Fernández, Ma Dolores (2015) "La gastronomía en la prensa española del siglo XIX". Estudios sobre el mensaje periodístico, 21, 1: 7-33. doi: http://dx.doi. org/10.5209/rev ESMP.2015.v21.n1.49078

Alvar, Manuel (1992) "Los diccionarios académicos y el problema de los neologismos". El neologismo necesario. http:/www.cervantesvirtual.com/obra-visor/los-diccionarios-acadmicos-y-elproblema-de-los-neologismos-0/html/01099ca2-82b2-11dfacc7-002185ce6064_6.html [accessed 07/December/2015].

Anderson, Lara (2013) Cooking up the Nation. Spanish Culinary Texts and Culinary Nationalization in the Late Nineteenth and Early Twentieth Century. Támesis, New York.

Anderson, Lara (2014) "The Unity and Diversity of La olla podrida: an Autochthonous Model of Spanish Culinary Nationalism". Journal of Spanish Cultural Studies, 14, 4: 400-414.

Arroyo, María (2016) "Ilustración publicitaria y vida cotidiana en las revistas gráficas: La Esfera (1920-1930). Historia y Comunicación Social, 21, 1: 189-202. http://dx.doi.org/10.5209/rev HICS.2016.v21.n1.52691

Ballarín, Pilar (1999) "Maestras, innovación y cambio". Arenal, 6, 1: $81-110$.

Bueno, Pilar and Ortega, Raimundo (1998) "De la fonda nueva a la nueva cocina. La evolución del gusto culinario en España durante los siglos XIX y XX". Revista de libros de la Fundación Cajamadrid, 19: 1-19. http://www.revistadelibros.com/articulos/evolucion-de-la-cocina-espanola-durante-los-siglos-xix-yxx. [accessed 18/September/2016].

Burgos, Carmen de (1918) La cocina moderna. Prometeo, Valencia.

Camba, Julio (2013) La casa de Lúculo. Catálogo de publicaciones del Ministerio de Educación, Cultura y Deporte, Colección Orellana 23, Madrid.

Echagüe, J. Antonio and Echagüe, Gonzalo (2013) Historia de la gastronomía (Esbozos). Real del Catorce editores, Madrid.

Elizalde Pérez-Grueso, M Molores (2000) "El 98 desde una perspectiva normalizadora. Una reflexión historiográfica de un centenario". Hispania, LX, 2: 707-736. doi: http://dx.doi. org/10.3989/hispania.2001.v61.i208.303

Ford, Richard (2008) Manual para viajeros por España y lectores en casa. Turner, Madrid.

Hernández Cano, Eduardo (2013) "Solitarios refugios de efemérides viejas. Monumentos y ciudades históricas como símbolos nacionales en la prensa gráfica (1918-1930)". Hispania, LXXIII, 44: 377-408. doi: http://dx.doi.org/10.3989/hispania.2013.011

Luján, Néstor and Perucho, Juan (1974) El libro de la cocina española: gastronomía e historia. Danae, Barcelona.

Martín, Eduardo (2008) Teodoro Bardají Mas. El precursor de la cocina moderna en España. E. Martín editor.

Martínez, Manuel (1981) Historia de la gastronomía española. Editora Nacional, Madrid.
Martín-Lorente, Manuel and Fernández Fernández, César (2014) "Aspectos de cultura y comunicación en el protocolo gastronómico y las prácticas de alimentación en diferentes etapas históricas". Historia y Comunicación Social, 19, Extra 3: 831842. DOI: http://dx.doi.org/10.5209/rev_HICS.2014.v19.46566.

Muro, Ángel (1894) El Practicón: tratado completo de cocina al alcance de todos y aprovechamiento de sobras. Librería de Miguel Guijarro, Madrid.

Pardo Bazán, Emilia (1913) La cocina española antigua. Renacimiento, Madrid.

Parra de Mas, Santiago (2008) "Fondas, hoteles y banquetes en la Zaragoza del siglo XIX". Cuadernos de Aragón, 38: 9-124. http://ifc.dpz.es/recursos/publicaciones/28/29/_ebook.pdf [accessed 07/October/2016]

Pérez, Dionisio (1929) Guía del buen comer español. Inventario y loa de la cocina clásica de España y sus regiones. Maxtor, Valladolid.

Pérez Samper, Ma de los Ángeles (1998) "Cataluña y Europa a la mesa: las recíprocas influencias en los modelos alimentarios de la Época Moderna". Pedralbes: Revista d'historia moderna, 18, 1: 251-272.

Pérez Samper, Ma de los Ángeles (2009) "La historia de la historia de la alimentación". Chronica nova: Revista de historia moderna de la Universidad de Granada, 35: 165-192.

Puga y Parga, Manuel Ma (1913) La cocina práctica. Tip. de El Noroeste.

Reglamento y plan de estudios de la Escuela Española de la Industria Hostelera [REEIH] (1909). A. Velasco Impresor, Madrid.

Renard, Marie-Christine and Thomé, Humberto (2016) "Cultural Heritage and Food Identity: The pre-Hispanic Salt of Zapotitlán Salinas, Mexico". Culture \& History Digital Journal, 5, 1. doi: http://dx.doi.org/10.3989/chdj.2016.004.

Sanz-Cañada, Javier and Muchnick, José (2016) "Geographies of Origin and Proximity: Approaches to Local Agro-Food Systems". Culture \& History Digital Journal, 5, 1. doi: http://dx. doi.org/10.3989/chdj.2016.002.

Simón, $M^{\mathrm{a}}$ del Carmen (1999) "Bibliofilia y gastronomía: una colección ejemplar". Pliegos de bibliofilia , 7: 27-32.

Simón, $\mathrm{M}^{\mathrm{a}}$ del Carmen (2003) Bibliografía de la gastronomía y la alimentación en España. Ediciones Trea, Gijón.

Simón, Ma del Carmen (2011) "Evolución de la profesión de cocinero: del primer estatuto a la primera exposición culinaria en Madrid (1758-1925)". Anales del Instituto de Estudios Madrileños, LI: 337-358. http://iemadrid.es/publicaciones/80/IEM-anales-tomoLI/. [accessed 18/February/2016].

Simón, $\mathrm{M}^{\mathrm{a}}$ del Carmen (2012) "Ignacio Domènech, autor y editor culinario". Cincinnati Romance Review, 33: 4-26. http://www. cromrev.com/volumes/vol33/vol33-complete.pdf. [accessed 25/ January/2016]

Simón, Mª del Carmen and Ansón, Rafael (1997) "Bibliografía universal de gastronomía". Cuenta y razón, 104: 123-132.

Thebussem, Dr. and Un cocinero de S. M. (1888) La mesa moderna. Cartas sobre el comedor y la cocina cambiadas entre el Doctor Thebussem y Un cocinero de S.M. Librerías de Fernando Fe y Leocadio López y sus corresponsales, Madrid.

Thebussem, Dr. and Valera, Juan (1906) NN KB CH por el Dr. Thebussem. En husa por Juan Valera. En escabeche y en sobremesa. Sucesores de Rivadeneira, Madrid.

Torre y Leyba, Ángel $\mathrm{M}^{\mathrm{a}}$ de la (1774) Economía de pretendientes. Diálogo entre Económico y Glotón. Imprenta de Francisco Xavier García, Madrid. 